\title{
PENGARUH KETERAMPILAN GURU MATEMATIKA MENGADAKAN VARIASI DALAM MENGGUNAKAN APLIKASI GOOGLE MEET DAN MOTIVASI MENGAJAR TERHADAP KINERJA PADA MASA PANDEMI
}

\author{
Yulia Saraswati \\ Dr. Tita Rosita, M.Pd dan Tian Abdul Aziz, Ph. D \\ yuliasaraswati7@gmail.com \\ Program Pasca Sarjana Universitas Terbuka
}

\begin{abstract}
Abstrak
Pada masa covid-19 Keterampilan guru mengajar menggunakan media daring menjadi factor kurangnya dalam pembelajaran. Kurangnya Keterampilan guru dipengaruhi oleh motivasi mengajar yang menurun saat pandemic. Akibatnya penurunan kinerja pada pembelajaran matematika inipun menurun.

Pada penelitian ini dilakukan bertujuan untuk mengetahui pengaruh keterampilan guru mengadakan variasi dalam menggunakan aplikasi Google Meet dan motivasi mengajar terhadap kinerja guru pada pembelajan matematika kelas $V$ di gugus II SD Kecamatan Jatiasih. Metode pada ini penelitian menggunakan metode survey dengan teknik pengumpulan data melalui angket Skala Likert. Metode pada ini penelitian menggunakan metode survei dengan teknik pengumpulan data melalui angket Skala Likert. Sampel yang digunakan Convenience Sampling dengan jumlah sampel 100 guru matematika SD. Teknik analisis data menggunakan regresi. Keterampilan guru mengadakan variasi dalam menggunakan aplikasi Google meet dan motivasi mengajar mempunyai pengaruh yang sigifikan terhadap kinerja guru dalam pembelajaran matematika kelas $V$ di SD gugus II kecamatan Jatiasih, dengan besar pengaruh Keterampilan guru mengadakan variasi dalam menggunakan aplikasi Google meet dan motivasi adalah 63,95 \%. Maka dapat disimpulkan bahwa adanya pengaruh keterampilan guru mengadakan variasi mengadakan variasi dalam menggunakan aplikasi Google Meet dan motivasi mengajar terhadap kinerja guru pada pembelajaran matematika kelas V di SD gugus II di kec. Jatiasih di masa pandemi.

Kata Kunci : Keterampilan mengadakan variasi, Motivasi Mengajar dan Kinerja
\end{abstract}

\section{PENDAHULUAN}

Guru merupakan faktor penting yang mempengaruhi terbentuknya siswa yang berkualitas. Gurupun menjadi ujung tombak yang berhadapan langsung dengan siswa baik melalui kegiatan pembelajaran di kelas maupun di luar kelas. Di tengah masa pandemik Covid-19 ini kebijakan pemerintah yang telah memberlakukan pembelajaran jarak jauh, tentu saja membuat semua tenaga pendidik harus mengikuti kebijakan dari pemerintah tersebut.

Pendidikan adalah salah satu sarana bagi peningkatan mutu sumber daya manusia (SDM). Mempunyai kompetensi merupakan hal yang essensial yang harus dimiliki oleh seorang guru. Kompetensi yang harus dimiliki oleh guru menjadi komponen penting dalam pendidikan ialah

Al-Madrasah: Jurnal Ilmiah Pendidikan Madrasah Ibtidaiyah

Vol. 6, No. 2, April-Juni 2022 
Yulia Saraswati, Tita Rosita, Tian Abdul Aziz : Pengaruh Keterampilan Guru Matematika Mengadakan Variasi Dalam Menggunakan Aplikasi Google Meet dan Motivasi Mengajar Terhadap Kinerja Pada Masa Pandemi

kompetensi pedagogik, kompetensi Keterampilan guru, kompetensi sosial, dan kompetensi professional.

Dengan pembelajaran jarak jauh tentunya siswa membutuhkan guru yang dapat memberikan pemahamannya dirumah. Keterampilan mengajar inilah termasuk ke dalam kompetensi profesional guru. Kompetensi professional yaitu kemampuan yang harus dimiliki guru dalam proses pembelajaran matematika. Karena bagi siswa pembelajaran matematika saat tatap muka saja sulit apalagi pada masa covid 19 ini yang serba terbatas.

Keterampilan mengajar di masa Covid 19 ini sangat dibutuhkan. Demi meningkatnya pembelajaran yang berkualitas baik untuk siswa maupun untuk kinerja guru. Keterampilan mengajar dalam menggunakan media e-learing ini perlu diperhatikan. Apalagi ditempat penelitian ini media yang digunakan pada pembelajaran e-learning ini menggunakkan aplikasi google meet sebagai perantara selama pembelajaran online berlangsung. Kurangnya Keterampilan mengajar menggunakan aplikasi google meet inipun berasal pada motivasi mengajar guru yang kurang. Dimana motivasi mengajar sangatlah berpengaruh kepada Keterampilan mengajar guru menggunakan aplikasi google meet. Jika motivasi dalam diri guru menurun maka Keterampilan gurupun menurun. Akhirnya akan berdampak pada kinerja guru.

Dari latar belakang masalah tersebut, Masalah-masalah yang ditemukan. Maka rumusan masalah sebagai berikut: "Apakah terdapat Pengaruh Keterampilan Guru Dalam Menggunakan Aplikasi Google Meet dan Motivasi Mengajar Guru terhadap Kinerja Guru Pembelajaran Matematika Kelas V di gugus II SD Kecamatan Jatiasih Kota Bekasi Jawa Barat?" dengan mengacu pada permasalahan, tujuan penelitian ini adalah Menganalisis pengaruh Keterampilan Guru Dalam Menggunakan Aplikasi Google Meet dan Motivasi Mengajar Guru terhadap Kinerja Guru Pembelajaran Matematika Kelas V di gugus II SD Kecamatan Jatiasih Kota Bekasi Jawa Barat?"

Selanjutnya terdapat empat hipotesis yang akan diusulkan: 1).Terdapat pengaruh Keterampilan guru dalam menggunakan aplikasi Google Meet terhadap kinerja guru pada mata pelajaran matematika kelas V di gugus II SD kec.Jatiasih? 2). Terdapat pengaruh motivasi mengajar guru terhadap kinerja guru kelas V digugus II SD Kec.Jatiasih? 3).Terdapat pengaruh motivasi mengajar guru terhadap Keterampilan guru dalam menggunakan aplikasi Google Meet pada pembelajaran matematika siswa kelas V di gugus II SD kec. Jatiasih? 4).Terdapat pengaruh

Al-Madrasah: Jurnal Ilmiah Pendidikan Madrasah Ibtidaiyah Vol. 6, No. 2, April-Juni 2022 
Yulia Saraswati, Tita Rosita, Tian Abdul Aziz : Pengaruh Keterampilan Guru Matematika Mengadakan Variasi Dalam Menggunakan Aplikasi Google Meet dan Motivasi Mengajar Terhadap Kinerja Pada Masa Pandemi

Keterampilan guru dalam menggunakan aplikasi Google Meet dan motivasi mengajar terhadap kinerja guru pada mata pelajaran matematika kelas V di gugus II SD kec.Jatiasih?

Mulyasa mengatakan bahwa "keterampilan dasar mengajar (teaching skills) ialah suatu karakteristik umum dari seseorang yang berhubungan dengan pengetahuan dan keterampilan yang diwujudkan melalui tindakan. ${ }^{1}$ Sedangkan keterampilan dasar mengajar (teaching skills) pada dasarnya merupakan suatu kakteristik umum dari seorang yang berhubungan dengan pengetahuan-pengetahuan dan keterampilan yang diwujudkan melalui tindakan. Sedangkan mengajar merupakan proses bimbingan kepada siswa dalam proses belajar. Selanjutya Howard berkata kalau proses mengajar ialah sesuatu aktivitas buat berupaya, membimbing seorang buat memperoleh, dan meningkatkan (skil), attitude, ideals (cita- cita), appreciations (penghargaan) serta pula knowledge. ${ }^{2}$ Menurut Emron Edison, keterampilan ialah adanya kemampuan kerja setiap individu yang mencakup aspek pengetahuan, keterampilan, dan sikap kerja yang sesuai dengan standar yang ditetapkan. ${ }^{3}$

Ruseffendi dalam Karso menerangkan jika matematika itu terorganisasikan dari unsurfaktor yang tidak didefinisikan, definisi- definisi, aksioma- aksioma, dan dalil- dalil, di mana dalil- dalil setelah dibuktikan kebenarannya berlaku secara umum, karna semacam itu matematika sering diucap ilmu deduktif

Terdapat delapan keterampilan dasar mengajar yang dianggap penting dalam menentukan keberhasilan proses belajar mengajar yaitu : 1) Keterampilan bertanya, 2) Keterampilan memberi penguatan, 3) Keterampilan mengadakan variasi, 4) ketempilan menjelaskan, 5) Keterampilan membuka dan menutup pelajaran, 6) keterampilam membimbing diskusi kelompok kecil, 7) Keterampilan mengelola kelas, dan 8) Keterampilan mengajar kelompok kecil dan perorangan. Namun pada penelitian ini Keterampilan yang akan diteliti yaitu Keterampilan mengadakan variasi. Indikator Keterampilan pada Keterampilan variasi mengajar terdapat tiga komponen komponen yaitu variasi mengajar, variasi media dan bahan ajar serta variasi, dan variasi pola interaksi guru dan siswa.

\footnotetext{
${ }^{1}$ Rusman, Model-Model Pembelajaran Mengembangkan Profesionalisme Guru (Jakarta: PT.Raja Grafindo Persada, 2018). 9 (2019).

2 Agus Gunawan, "Bab II Landasan Teori,” Journal of Chemical Information and Modeling 53, no.

${ }^{3}$ Ancah Caesarina Novi Marchianti, Elly Nurus Sakinah, dan Nurud Diniyah, "Efektifitas Penyuluhan Gizi Pada Kelompok 1000 HPK Dalam Meningkatkan Pengetahuan Dan Sikap Kesadaran Gizi," Journal of Agromedicine and Medical Sciences 3, no. 3 (2017).
}

Al-Madrasah: Jurnal Ilmiah Pendidikan Madrasah Ibtidaiyah Vol. 6, No. 2, April-Juni 2022 
Yulia Saraswati, Tita Rosita, Tian Abdul Aziz : Pengaruh Keterampilan Guru Matematika Mengadakan Variasi Dalam Menggunakan Aplikasi Google Meet dan Motivasi Mengajar Terhadap Kinerja Pada Masa Pandemi

Kerampilan guru saat belajar daring menggunakan aplikasi Google Meet sebagai media pembelajaran daring berbasi video conferens antara guru dan siswa. Google meet. Menurut Rosenberg e-learning pada pengunaan teknologi internet umtuk mengirim serangkain solusi yang ingin meningkatkan pengetahuan dan keterampilan. ${ }^{4}$ Menurut Wijayanto, Google Meet adalah produk dari google yang merupakan layanan komunikasi video yang dikembangkan oleh google. ${ }^{5}$ Softwer ini gratis, dan memberikan fitur terbaik dengan menampilkan video yang berkualitas terbaik. Maka dapat disimpulkan bahwa kerampilan guru menggunkan aplikasi Google Meet merupakan kemampuan atau keterampilan guru untuk merubah proses kegiatan belajar yang menarik melalui video conferens yaitu Google Meet sebagai media pembelajaran ajata guru dan siswa. Dimana guru dalam proses mpengajarannya menggunakan berbagai variasi mengajar yang menarik perhatian siswa.

Maka dapat disimpulkan bahwa kerampilan guru menggunkan aplikasi Google Meet merupakan kemampuan atau keterampilan guru untuk merubah proses kegiatan belajar yang menarik melalui video conferens yaitu Google Meet sebagai media pembelajaran ajata guru dan siswa. Dimana guru dalam proses mpengajarannya menggunakan berbagai variasi mengajar yang menarik perhatian siswa. Untuk menumbuhkan Keterampilan yang dimiliki oleh guru semua berasal dari motivasi mengajar diri sendiri jika motivasi yang ada dalam diri rendah maka Keterampilan yang dimiliki gurupun akan rendah, begitupun sebalikanya jika motivasi guru tinggi maka Keterampilan yang dimiliki oleh gurupun meningkat. Motivasi merupakan akar dari kata bahasa latin yaitu Movore, yang berarti gerak atau dorongan untuk bergerak atau yang menggerakan. Motivasi merupakan salah satu yang mempengarui prilaku manusia itu sendiri.

Motivasi sering disebut-sebut sebagai pendorong, keinginan, pendukung atau kebutuhankebutuhan yang bisa membuat seseorang bersemangat dan termotivasi untuk mengurangi dan memenuhi dorongan itu sendiri,sehingga dapat bertindak dan berbuat menurut cara cara tertentu yang akan membawa kearah yang optimal Motivasi mengajarpun memiliki pengertian menurut para ahli yaitu menurut Tomas M.Risk yang berpendapat bahwa "Motivasi adalah usaha yang disadari oleh pihak guru untuk menimbulkan motif-motif pada diri siswa yang menunjang kearah

${ }^{4}$ Fathinatul Utammimah, E-Book Pengantar E-Learning Dalam Dunia Pendidikan Modern (Malang: UIN Maliki Press (Aggota IKPI), 2015).

5 A. Wijayanto dan S. Yunis dkk., Strategi Pembelajaran PJKR Selama Covid-19 (1st Ed.). (Tulungagung: Akademia Pustaka, 2020).

Al-Madrasah: Jurnal Ilmiah Pendidikan Madrasah Ibtidaiyah Vol. 6, No. 2, April-Juni 2022 
Yulia Saraswati, Tita Rosita, Tian Abdul Aziz : Pengaruh Keterampilan Guru Matematika Mengadakan Variasi Dalam Menggunakan Aplikasi Google Meet dan Motivasi Mengajar Terhadap Kinerja Pada Masa Pandemi

tujuan-tujuan belajar. ${ }^{6}$ Abraham Maslow menyatakan, bahwa motivasi adalah sesuatu yang bersifat tetap, tidak pernah berakhir, berfluktuasi dan bersifat kompleks, dan hal itu kebanyakan merupakan karakter universal pada setiap kegiatan organisme. ${ }^{7}$

Maslow juga mengemukakan bahwa kebutuhan manusia dapat diklasifikasikan kan ke dalam 5 kebutuhan hierarkin sebagai berikut: 1) Kebutuhan fisiologis merupakan kebutuhan berupa makan perumahan dan pakaian. 2) Kebutuhan rasa aman (safety) merupakan kebutuhan rasa aman dan selamatan.3) Kebutuhan pengakun sistem(esteem) merupakan kebutuhan penghargaan prestasi diri. 4) Kebutuhan aktualisasi diri merupakan kebutuhan puncak yang menyebabkan kan seorang bertindak bukan atas dorongan orang lain tetapi karena kesadaran dan keinginan diri sendiri.

Faktor-faktor yang mempengaruhi motivasi menurut Hamalik memiliki 2 komponen yaitu : Komponen dari dalam dan komponen dari luar. ${ }^{8}$ Motivasi Intrinsik sebab dalam diri tiap orang sudah ada dorongan guna melaksanakan suatu. Motivasi intrinsik bisa pula dikatakan selaku wujud motivasi yang didalamnya kegiatan mengajar diawali serta diteruskan bersumber pada dorongan dari dalam diri serta secara mutlak berkait dengan kegiatan mengajar. Motivasi ekstrinsik bisa pula dikatakan selaku wujud motivasi yang didalamya kegiatan belajar diawali serta diteruskan bersumber pada dorongan dari luar yang tidak secara mutlak berkaitan dengan kegiatan belajar Indikator motivasi yang pengaruhi motivasi mengajar guru terdapat 2, ialah aspek ekstern( aspek yang berasal dari luar diri seorang) serta aspek internal( aspek yang berasal dari dalam diri seorang).

Kinerja berasal dari kata performance dalam bahasa Inggris yang memiliki tiga makna yaitu: prestasi, pertunjukan, dan pelaksanaan tugas. Ruky mengatakan bahwa kinerja menghadirkan fungsi dan kemampuan (ability), motivasi (motivation), dan kesempatan (opportunity). ${ }^{9}$ Dengan demikian, kinerja ditentukan atau dipengaruhi oleh faktor-faktor kemampuan, motivasi, dan kesempatan.

Faktor-faktor yang pengaruhi kinerja menurut Mangkunegara ialah: Faktor kemampuan: Secara psikologis keahlian pegawai terdiri dari keterampilan serta keahlian realita (pembelajaran), oleh sebab itu pegawai perlu ditempatkan pada pekerjaan yang cocok dengan keahliannya. Faktor

\footnotetext{
${ }^{6}$ Rusman, Model-Model Pembelajaran Mengembangkan Profesionalisme Guru.

${ }^{7}$ Rusman.

${ }^{8}$ R. Ahmadi, Profesi Keguruan Konsep \& Strategi Mengembangkan Profesi \& Karier Guru (Depok: Aa-Ruzz Media, 2018).

${ }^{9}$ Supardi, Kinerja Guru (Jakarta: Rajawali Pers, 2016).
}

Al-Madrasah: Jurnal Ilmiah Pendidikan Madrasah Ibtidaiyah Vol. 6, No. 2, April-Juni 2022 
Yulia Saraswati, Tita Rosita, Tian Abdul Aziz : Pengaruh Keterampilan Guru Matematika Mengadakan Variasi Dalam Menggunakan Aplikasi Google Meet dan Motivasi Mengajar Terhadap Kinerja Pada Masa Pandemi

motivasi : Motivasi tercipta dari perilaku (attitude) seseorang pegawai dalammengahdapi suasana (situation) kerja, motivasi ialah keadaan yangmenggerakan diri pegawai yang terencana buat menggapai sesuatu tujuandalam oragnisasi( tujuan kerja). ${ }^{10}$

Jadi, dapat disimpulkan dari beberapa pendapat diatas bahwa kinerja yang baik dapat memperhatikan factor-faktor yang dapat mempengaruhinya dan ini artinya upaya yang dilakukan kinerja seseorang agar terarah sesuai keinginan. Faktor-faktor tersebut yaitu berasal dari dalam (intern) dan factor dari luar (ekstern). Faktor faktor inilah yang dapat mempengaruhi kualitas kerja pada seseorang.

\section{METODE PENELITIAN}

Penelitian ini yang dilaksanakan di SD kecamatan Jatiasih Gugus II. Penelitian ini menggunakan penelitian kuantitatif dengan metode survey. Penelitian survei ini dilakukan untuk mendapatkan gambaran mengenai keterampilan guru mengadakan variasi mengadaakan variasi dalam aplikasi Google Meet terhadap kinerja guru pada mata pelajaran matematika. Pada penelitian ini menggunakan analisis regresi yang bertujuan untuk menjelaskan terdapatnya ikatan sebab- akibat yang bersama mempengaruhi serta berhubungan antar variabel dalam penelitian melalui uji hipotesis statistik.

Dalam penelitian ini yang menjadi populasinya adalahsemua guru kelas V di gugus II SD Kecamatan Jatiasih Kota Bekasi Jawa Barat baik negeri maupun swasta yang berjumlah 140 orang. Pada sampel penelitian ini menggunakan non probability sampling dengan teknik convenience sampling. Menurut Sugiono, convenience sampling ialah teknik pada penentuan sampel dengan memilih sampel secara bebas sesuai keinginan peneliti dengan taraf kesalahan 5\% maka didapat hasil dari rumus slovin berjumlah 100 orang yang menjadi responden. ${ }^{11}$

Untuk mendapatkan data dalam penelitian ini menggunakan pengumpulan data yaitu angket (kuesioner). Sugiono mengatakan bahwa "Kuesioner adalah teknik pengumpulan data yang dilakukan dengan cara memberi seperangkat pertanyaan atau pernyataan tertulis kepada responden untuk dijawabnya". ${ }^{12}$

\footnotetext{
${ }^{10}$ Mangkunegara, Manajemen Sumber Daya Manusia Perusahaan (Bandung : Remaja Rosdakarya, 2016).

${ }^{11}$ Sugiono, Metode Penelitian Kuantitatif, Kualitatif, Dan R\&D (Bandung: Alfabeta, 2019)

12 Sugiono.
}

Al-Madrasah: Jurnal Ilmiah Pendidikan Madrasah Ibtidaiyah

Vol. 6, No. 2, April-Juni 2022 
Yulia Saraswati, Tita Rosita, Tian Abdul Aziz : Pengaruh Keterampilan Guru Matematika Mengadakan Variasi Dalam Menggunakan Aplikasi Google Meet dan Motivasi Mengajar Terhadap Kinerja Pada Masa Pandemi

Berikutnya menurut Dr. Sudayono yang berpendapat bahwa "Kuesioner adalah suatu teknik atau cara pengumpulan data yang berisi sejumlah pertanyaan atau pernyataan yang harus dijawab responden". ${ }^{13}$ Data dikumpulkan dari 100 responden dimana setiap responden mengisi kuesioner yang sudah dibuat melalui google form yang dibagikan kepada guru untuk mengisi kuesioner Keterampilan dan motivasi. Sedangkan kinerja diperoleh dari hasil pengisian kepala sekolah. Metode analisis datanya menggunkan regresi sederahana, regresi berganda dan kolerasi antar setiap variabel.

\section{HASIL DAN PEMBAHASAN}

Hasil penelitian ini diperoleh dari data pengolahan instrumen angket yang telah diisi oleh responden. Pengolahan hasil data penelitian menggunakan aplikasi penghitungan SPSS versi 25 untuk mengukur seberapa besar pengaruh variabel Keterampilan guru menggunakan aplikasi google meet $\left(\mathrm{X}_{1}\right)$ dan variabel motivasi mengajar $\left(\mathrm{X}_{2}\right)$ terhadap variabel kinerja guru $(\mathrm{Y})$.

Tabel 4.8

Rangkuman Statistik Sederhana Setiap Variabel

\begin{tabular}{|l|r|r|r|}
\hline & $\begin{array}{r}\text { Keterampilan } \\
\left(\mathrm{X}_{1}\right)\end{array}$ & \multicolumn{1}{|c|}{$\begin{array}{c}\text { Motivasi } \\
\left(\mathrm{X}_{2}\right)\end{array}$} & \multicolumn{2}{|c|}{ Kinerja } \\
$(\mathrm{Y})$
\end{tabular}

Berdasarkan perhitungan pada tabel diatas, pada $\left(\mathrm{X}_{1}\right)$ diperoleh skor terendah 69 dan tertinggi 150 Dengan demikian, jangkauan nilai skor sebesar 81 Data nilai skor Keterampilan

${ }^{13}$ Dr.Sudayono, Metode Penelitian Pendidikan (Jakarta: Kencana, 2016).

Al-Madrasah: Jurnal Ilmiah Pendidikan Madrasah Ibtidaiyah Vol. 6, No. 2, April-Juni 2022 
Yulia Saraswati, Tita Rosita, Tian Abdul Aziz : Pengaruh Keterampilan Guru Matematika Mengadakan Variasi Dalam Menggunakan Aplikasi Google Meet dan Motivasi Mengajar Terhadap Kinerja Pada Masa Pandemi

guru dalam menggunakan aplikasi Google Meet dapat disajikan dalam bentuk tabel distribusi frekuensi kelompok yang terdiri atas 8 kelas interval dengan panjang interval 11. rata-rata skor Keterampilan guru dalam menggunakan aplikasi Google Meet adalah sebesar 114,37 hasil perhitungan median sebesar 113,46 Standar deviasi atau simpang baku skornya sebesar 16,08 dan varian sebesar 258,52 Dalam tabel dapat dilihat bahwa skor Keterampilan guru dalam menggunakan aplikasi Google Meet yang memiliki jumlah paling banyak yaitu 28 responden berada pada kelas interval 102-112.

Sedangkan pada varibel $\mathrm{X}_{2}$ diperoleh skor terendah 83 dan tertinggi 168 Dengan demikian, jangkauan nilai skor sebesar 85 Data nilai skor motivasi guru dapat disajikan dalam bentuk tabel distribusi frekuensi kelompok yang terdiri atas 8 kelas interval dengan panjang interval 11. Nilai rata-rata skor motivasi guruadalah sebesar 12914. hasil perhitungan lainnya diketahui bahwa modus sama dengan 123,91 dan median sebesar 128,00 Standar deviasi atau simpang baku skornya sebesar 17,76 dan varian sebesar 315,51 Dalam tabel dapat dilihat bahwa skor motivasi guru yang memiliki jumlah paling banyak yaitu 26 responden berada pada kelas interval 116-126.

Untuk Varibel Y diperoleh skor terendah 75 dan tertinggi 166 Dengan demikian, jangkauan nilai skor sebesar 91 Data nilai skor kinerja guru dapat disajikan dalam bentuk tabel distribusi frekuensi kelompok yang terdiri atas 8 kelas interval dengan panjang interval 12. Ratarata skor kinerja guru adalah sebesar 127,18 hasil perhitungan lainnya diketahui bahwa modus sama dengan 124,50 dan median sebesar 124,50 Standar deviasi atau simpang baku skornya sebesar 18,52 dan varian sebesar 343,02 Dalam tabel dapat dilihat bahwa skor motivasi guru yang memiliki jumlah paling banyak yaitu 27 responden berada pada kelas interval 123-134.

\section{1) Signifikansi dan Linieritas Regresi Keterampilan dan Kinerja}

\begin{tabular}{|c|c|c|c|c|c|c|c|c|}
\hline \multicolumn{9}{|c|}{ Coefficients $^{\mathrm{a}}$} \\
\hline & \multirow{2}{*}{ Model } & \multicolumn{2}{|c|}{$\begin{array}{c}\text { Unstandardized } \\
\text { Coefficients }\end{array}$} & \multirow{2}{*}{$\begin{array}{c}\text { Standardized } \\
\text { Coefficients } \\
\text { Beta }\end{array}$} & \multirow{2}{*}{$\mathrm{T}$} & \multirow{2}{*}{ Sig. } & \multicolumn{2}{|c|}{$\begin{array}{l}\text { Collinearity } \\
\text { Statistics }\end{array}$} \\
\hline & & B & $\begin{array}{l}\text { Std. } \\
\text { Error }\end{array}$ & & & & Tolerance & VIF \\
\hline \multirow{2}{*}{1} & (Constant) & 53,348 & 11,035 & & 4,834 & 0,000 & & \\
\hline & KETERAMPILAN & 0,657 & 0,096 & 0,571 & 6,878 & 0,000 & 1,000 & 1,000 \\
\hline
\end{tabular}

a. Dependent Variable: Y.KINERJA

Al-Madrasah: Jurnal Ilmiah Pendidikan Madrasah Ibtidaiyah Vol. 6, No. 2, April-Juni 2022 
Yulia Saraswati, Tita Rosita, Tian Abdul Aziz : Pengaruh Keterampilan Guru Matematika Mengadakan Variasi Dalam Menggunakan Aplikasi Google Meet dan Motivasi Mengajar Terhadap Kinerja Pada Masa Pandemi

Setelah dilakukan perhitungan dan analisis terhadap data kinerja dengan Keterampilan guru didapat persamaan regresi $\mathrm{Y}=53,35+0,66 \mathrm{X} 1$. Untuk melihat apakah persamaan regresi tersebut linier atau tidak dilakukan uji linieritas regresi dan uji signifikansi regresi . Hal ini berarti bahwa garis persamaan regresi $\mathrm{Y}=53,35+0,66 \mathrm{X} 1$ adalah linier. Dengan demikian dapat dikatakan bahwa pengaruh Keterampilan terhadap kinerja adalah sangat signifikan dan linier. Model regresi tersebut mengandung arti bahwa apabila Keterampilan ditingkatkan satu poin, maka kinerja guru cenderung meningkat sebesar 0,66 poin pada konstanta 53,35. pengujian koefisien korelasi dengan Pearson Product Moment terhadap hubungan antara Keterampilan guru (X1) dengan kinerja (Y). Dari hasil perhitungan diperoleh koefisien korelasi $r=0,57$.

2) Signifikansi dan Linieritas Regresi Motivasi dan Kinerja

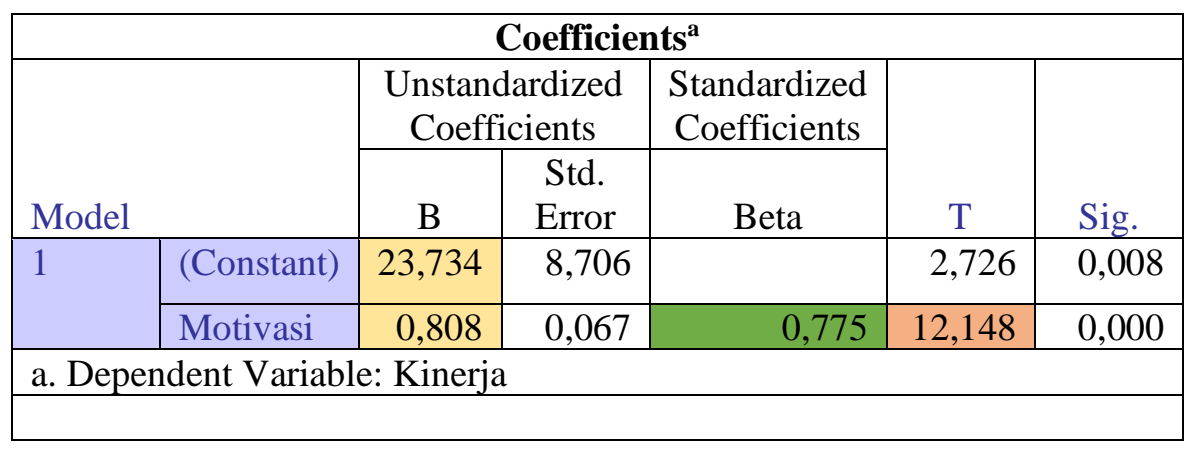

Perhitungan dan analisis terhadap data kinerja dengan motivasi didapat persamaan regresi $\mathrm{Y}=23,73+0,66 \mathrm{X} 2$. Untuk melihat apakah persamaan regresi tersebut linier atau tidak dilakukan uji signifikansi regresi dan uji linieritas regresi. Hal ini berarti bahwa garis persamaan regresi $\mathrm{Y}=23,73+0,66 \mathrm{X} 2$ adalah linier. Dengan demikian dapat dikatakan bahwa pengaruh motivasi terhadap kinerja adalah sangat signifikan dan linier. Model regresi tersebut mengandung arti bahwa apabila motivasi ditingkatkan satu poin, maka kinerja guru cenderung meningkat sebesar 0,66 poin pada konstanta 23,73. Pengujian koefisien korelasi dengan Pearson Product Moment terhadap hubungan antara Motivasi (X2) dengan kinerja (Y). Dari hasil perhitungan diperoleh koefisien korelasi $\mathrm{r}=0,78$

Al-Madrasah: Jurnal Ilmiah Pendidikan Madrasah Ibtidaiyah

Vol. 6, No. 2, April-Juni 2022 
Yulia Saraswati, Tita Rosita, Tian Abdul Aziz : Pengaruh Keterampilan Guru Matematika Mengadakan Variasi Dalam Menggunakan Aplikasi Google Meet dan Motivasi Mengajar Terhadap Kinerja Pada Masa Pandemi

\section{3) Signifikansi dan Linieritas Regresi Motivasi Dan Keterampilan Guru.}

\begin{tabular}{|c|c|c|c|c|c|c|}
\hline \multicolumn{7}{|c|}{ Coefficients $^{\mathbf{a}}$} \\
\hline \multirow{2}{*}{\multicolumn{2}{|c|}{ Model }} & \multicolumn{2}{|c|}{$\begin{array}{l}\text { Unstandardized } \\
\text { Coefficients }\end{array}$} & \multirow{2}{*}{$\begin{array}{c}\text { Standardized } \\
\text { Coefficients } \\
\text { Beta }\end{array}$} & \multirow[b]{2}{*}{$\mathrm{t}$} & \multirow[b]{2}{*}{ Sig. } \\
\hline & & B & $\begin{array}{l}\text { Std. } \\
\text { Error }\end{array}$ & & & \\
\hline \multirow[t]{2}{*}{1} & (Constant) & 69,485 & 11,333 & & 6,131 & 0,000 \\
\hline & KETERAMPILAN & 0,526 & 0,098 & 0,476 & 5,360 & 0,000 \\
\hline
\end{tabular}

a. Dependent Variable: MOTIVASI

Perhitungan dan analisis terhadap data Keterampilan guru dengan motivasi didapat persamaan regresi X2 $=69,48+0,53 X 1$. Untuk melihat apakah persamaan regresi tersebut linier atau tidak dilakukan uji signifikansi regresi dan uji linieritas regresi. Hal ini berarti bahwa garis persamaan regresi X2 $=69,48+0,53 X 1$ adalah linier. Dengan demikian dapat dikatakan bahwa pengaruh motivasi terhadap Keterampilan guru mengadakan variasi dalam menggunakan aplikasi Google Meet adalah sangat signifikan dan linier. Model regresi tersebut mengandung arti bahwa apabila motivas ditingkatkan satu poin, maka Keterampilan guru mengadakan variasi dalam menggunakan aplikasi Google Meet cenderung meningkat sebesar 0,53 poin pada konstanta 69,48. dilakukan pengujian koefisien korelasi dengan Pearson Product Moment terhadap hubungan antara Motivasi (X2) dengan Keterampilan guru (X1). Dari hasil perhitungan diperoleh koefisien korelasi $r=0,47$.

\section{4). Signifikansi Dan Linieritas Regresi Berganda Variabel Kinerja (Y) Atas Keterampilan Guru Mengadakan Variasi Dalam Menggunakan Aplikasi Google Meet (X1) Dan Motivasi Mengajar (X2) .}

Setelah dilakukan perhitungan dan analisis terhadap data Keterampilan guru mengadakan variasi dalam menggunakan aplikasi Google Meet dengan motivasi didapat persamaan regresi $\mathrm{Y}=$ $6,174+0,300 \mathrm{X}_{1}+0,679 \mathrm{X}_{2}$. Untuk melihat apakah persamaan regresi tersebut linier atau tidak dilakukan uji signifikansi regresi dan uji linieritas regresi. Hal ini berarti bahwa garis persamaan regresi $\mathrm{Y}=6,174+0,300 \mathrm{X}_{1+} 0,679 \mathrm{X}_{2}$ adalah linier.

Dengan demikian dapat dikatakan bahwa pengaruh motivasi terhadap Keterampilan guru adalah sangat signifikan dan linier. Model regresi tersebut mengandung arti bahwa apabila Keterampilan guru mengadakan variasi dalam menggunakan aplikasi Google Meet ditingkatkan

Al-Madrasah: Jurnal Ilmiah Pendidikan Madrasah Ibtidaiyah Vol. 6, No. 2, April-Juni 2022 
Yulia Saraswati, Tita Rosita, Tian Abdul Aziz : Pengaruh Keterampilan Guru Matematika Mengadakan Variasi Dalam Menggunakan Aplikasi Google Meet dan Motivasi Mengajar Terhadap Kinerja Pada Masa Pandemi

satu poin 0,30 dan motivasi ditingkatkan satu poin 0,67 , maka kinerja guru cenderung meningkat dengan konstanta 6,174 .

Tabel 4.23

Koefisien Korelasi Pengaruh Variabel X1 dan X2 Terhadap Y

\begin{tabular}{|l|c|c|c|c|}
\hline \multicolumn{5}{|c|}{ Model Summary } \\
\hline Model & $\mathrm{R}$ & R Square & $\begin{array}{c}\text { Adjusted R } \\
\text { Square }\end{array}$ & $\begin{array}{c}\text { Std. Error of the } \\
\text { Estimate }\end{array}$ \\
\hline 1 & $\mathbf{. 8 0 8}^{\mathrm{a}}$ & .653 & \multicolumn{3}{|c|}{.646} & 11.015 \\
\hline $\begin{array}{l}\text { a. Predictors: (Constant), Motivasi mengajar, Keterampilan guru } \\
\text { menggunakan google meet }\end{array}$ \\
\hline
\end{tabular}

Perhitungan Regresi berganda Variabel X1 dan X2 Terhadap Y Uji Signifikansi Model Regresi (Uji - F)

\begin{tabular}{|c|c|c|c|c|c|c|}
\hline \multicolumn{7}{|c|}{ ANOVA $^{\mathbf{a}}$} \\
\hline \multicolumn{2}{|c|}{ Model } & $\begin{array}{l}\text { Sum of } \\
\text { Squares }\end{array}$ & df & $\begin{array}{l}\text { Mean } \\
\text { Square }\end{array}$ & $\mathrm{F}$ & Sig. \\
\hline \multirow[t]{3}{*}{1} & $\begin{array}{l}\text { Regressi } \\
\text { on }\end{array}$ & $\begin{array}{r}22189.92 \\
9\end{array}$ & 2 & $\begin{array}{r}11094.96 \\
4\end{array}$ & 91.444 & $.000^{\mathrm{b}}$ \\
\hline & Residual & $\begin{array}{r}11769.03 \\
1\end{array}$ & 97 & 121.330 & & \\
\hline & Total & $\begin{array}{r}33958.96 \\
0\end{array}$ & 99 & & & \\
\hline \multicolumn{7}{|c|}{ a. Dependent Variable: Kinerja } \\
\hline \multicolumn{7}{|c|}{$\begin{array}{l}\text { b. Predictors: (Constant), Motivasi mengajar, Keterampilan } \\
\text { guru menggunakan google meet }\end{array}$} \\
\hline
\end{tabular}

Tabel 4.6

Rekapitulasi Hasil Pengujian Hipotesis

\begin{tabular}{|c|c|c|c|c|c|c|c|}
\hline \multirow{3}{*}{ No } & \multirow{3}{*}{ Hipotesis } & \multirow{3}{*}{ Uji Statistik } & \multirow{3}{*}{$\begin{array}{r}\text { Keputusa } \\
\mathbf{n} \mathbf{H}_{\mathrm{o}}\end{array}$} & \multicolumn{3}{|c|}{ Uji Signifikansi-t } & \multirow{3}{*}{$\begin{array}{l}\text { Kesimpula } \\
\text { n }\end{array}$} \\
\hline & & & & \multirow{2}{*}{ thitung } & T tabel & & \\
\hline & & & & & $\alpha=$ & & \\
\hline 1. & $\begin{array}{l}\text { Keterampilan guru } \\
\text { menggunakan aplikasi } \\
\text { google meet } \\
\text { berpengaruh terhadap } \\
\text { Kinerja }\end{array}$ & $\begin{array}{l}\mathrm{H}_{\mathrm{o}}: \rho_{\mathrm{x} 1 . \mathrm{y}}=0 \\
\mathrm{H}_{1}: \rho_{\mathrm{X} 1 . \mathrm{y}}>0\end{array}$ & $\begin{array}{l}\mathrm{H}_{0} \\
\text { ditolak, } \\
\mathrm{H} 1 \\
\text { diterima }\end{array}$ & $6,88^{* *}$ & 1,66 & $\begin{array}{r}13,50 \\
\%\end{array}$ & $\begin{array}{l}\text { Berpengaru } \\
\mathrm{h}\end{array}$ \\
\hline
\end{tabular}

Al-Madrasah: Jurnal Ilmiah Pendidikan Madrasah Ibtidaiyah

Vol. 6, No. 2, April-Juni 2022 
Yulia Saraswati, Tita Rosita, Tian Abdul Aziz : Pengaruh Keterampilan Guru Matematika Mengadakan Variasi Dalam Menggunakan Aplikasi Google Meet dan Motivasi Mengajar Terhadap Kinerja Pada Masa Pandemi

\begin{tabular}{|c|c|c|c|c|c|c|c|}
\hline 2. & $\begin{array}{l}\text { Motivasi mengajar } \\
\text { berpengaruh terhadap } \\
\text { kinerja }\end{array}$ & $\begin{array}{l}H_{0}: \rho_{x 2 . y}=0 \\
H_{1}: \rho_{x} 2 . y>0\end{array}$ & $\begin{array}{l}\mathrm{H}_{0} \text { ditolak, } \\
\mathrm{H} 1 \\
\text { diterima }\end{array}$ & $12,15 * *$ & 1,66 & $\begin{array}{c}50,45 \\
\%\end{array}$ & $\begin{array}{l}\text { Berpengaru } \\
\mathrm{h}\end{array}$ \\
\hline 3. & $\begin{array}{l}\text { Motivasi mengajar } \\
\text { berpengaruh terhadap } \\
\text { kinerja Keterampilan } \\
\text { guru menggunakan } \\
\text { aplikasi google meet }\end{array}$ & $\begin{array}{l}\mathrm{H}_{\mathrm{O}}: \rho_{\mathrm{X} 1 . \mathrm{x} 2}=0 \\
\mathrm{H}_{1}: \rho_{\mathrm{X} 1 . \mathrm{x} 2}>0\end{array}$ & $\begin{array}{l}\mathrm{H}_{0} \text { ditolak, } \\
\mathrm{H} 1 \text { diterima }\end{array}$ & $5,36 * *$ & 1,66 & $22,84 \%$ & $\begin{array}{l}\text { Berpengaru } \\
\mathrm{h}\end{array}$ \\
\hline 4. & $\begin{array}{l}\text { Kinerja Keterampilan } \\
\text { guru menggunakan } \\
\text { aplikasi google meet } \\
\text { dan motivasi mengajar } \\
\text { terhadap kinerja }\end{array}$ & $\begin{array}{l}\mathrm{H}_{\mathrm{O}}: \rho_{\mathrm{X} 1 \mathrm{x} 2 . \mathrm{y}=0} \\
\mathrm{H}_{1}: \rho_{\mathrm{x} 1 \mathrm{x} 2 . \mathrm{y}>0}\end{array}$ & $\begin{array}{l}\mathrm{H}_{0} \text { ditolak } \\
\mathrm{H}_{0} \text { ditolak, } \\
\mathrm{H} 1 \text { diterima }\end{array}$ & 91,44 & 1,66 & $\begin{array}{c}63,95 \\
\%,\end{array}$ & Berpengaruh \\
\hline
\end{tabular}

Pembahasan :

\section{Pengaruh variabel keterampilan guru mengadakan variasi dalam menggunakan google} meet

Terhadap variabel Kinerja sebesar 6,88 lebih besar dari pada ttabel $=1$, Pengaruh Keterampilan guru terhadap kinerja

Hasil perhitungan pengaruh Keterampilan guru mengadakan variasi menggunakan Google Meet terhadap Kinerja, diperoleh koefisien sebesar 0.57. Dalam penelitian ini ditentukan pengaruh tersebut signifikan atau tidak bila thitung $>$ ttabel. Tetapi bila thitung $\leq$ ttabel, maka dinyatakan tidak terdapat pengaruh langsung. Ternyata nilai thitung 66 untuk $\alpha=$ 0,05 dengan $\mathrm{dk}=96$, maka dapat disimpulkan bahwa terdapat pengaruh langsung positif keterampilan guru mengadakan variasi menggunakan Google Meet terhadap kinerja. Berdasarkan pembuktian emperik yang telah didapat, maka dapat disimpulkan bahwa penlitian ini menunjukan bahwa keterampilan adalah kemampuan dalam melaksanakan tugas berdasarkan kompetensi pekerjaan dan hasilnya dapat diamati.

\section{Pengaruh Motivasi terhadap kinerja}

Hasil perhitungan pengaruh Keterampilan guru menggunakan Google Meet terhadap Kinerja, Dalam penelitian ini menunjukan pengaruh thitung > ttabel. Ternyata nilai thitung untuk pengaruh variabel keterampilan guru mengadakan variasi menggunakan Google Meet terhadap variabel kinerja yang dihasilkan lebih besar dari pada ttabel, maka dapat disimpulkan bahwa terdapat pengaruh secara signifikan keterampilan guru menggunakan Google Meet

Al-Madrasah: Jurnal Ilmiah Pendidikan Madrasah Ibtidaiyah

Vol. 6, No. 2, April-Juni 2022 
Yulia Saraswati, Tita Rosita, Tian Abdul Aziz : Pengaruh Keterampilan Guru Matematika Mengadakan Variasi Dalam Menggunakan Aplikasi Google Meet dan Motivasi Mengajar Terhadap Kinerja Pada Masa Pandemi

terhadap kinerja.

Berdasarkan pembuktian emperik, maka dapat disimpulkan bahwa penelitian ini menunjukan motivasi merupakan salah satu variabel yang sangat penting dan berpengaruh langsung terhadap kinerja. seseorang yang memiliki motivasi tinggi, cenderung memiliki tingkat yang lebih besar terhadap pelaksanaan tugas.

Secara teoritis, pengaruh motivasi terhadap kinerja diilustrasikan bahwa motivasi merupakan kekuatan yang terdapat dalam seorang, yang mendorong perilakunya untuk melaksanakan tindakan. Besarnya ketekunan kekuatan dari dalam diri seorang untuk melaksanakan suatu tugas ataupun mencapai target memperlihatkan sepanjang mana tingkatan motivasinya.

\section{Pengaruh Motivasi dan Keterampilan}

Hasil perhitungan pengaruh motivais mengajar guru terhadap kinerja, diperoleh pengaruh tersebut signifikan dimana thitung $>$ ttabel. Ternyata nilai thitung untuk pengaruh variabel motivasi mengajar terhadap variabel keterampilan guru lebih besar dari pada ttabel, maka dapat disimpulkan bahwa terdapat pengaruh signifikan motivasi terhadap keterampilan guru. Berdasarkan pembuktian emperik, maka dapat disimpulkan bahwa penelitian ini menunjukan motivasi merupakan salah satu variabel yang sangat penting dan berpengaruh langsung terhadap keterampilan guru. Sejalan dengan teori Bafadal yang menyatakan bahwa seseorang akan bekerja secara profesional jika ia memiliki keetrampilan dan motivasi. artinya seseorang yang bekerja secara profesional jika ingin memiliki keterampilan kerja yang tinggi dan memiliki motivasi yang tinggi untuk mengerjakan dengan sebaik-baiknya, artinya, motivasi merupakan komponen penting dan dapat berpengaruh terhadap kinerja.

\section{Pengaruh keterampilan guru menggunakan aplikasi google meet dan motivasi mengajar terhadap kinerja.}

Hasil perhitungan pengaruh keterampilan guru mengadakan variasi menggunakan aplikasi Google Meet dan motivasi mengajar guru terhadap kinerja. dalam penelitian ini ditentukan pengaruh tersebut signifikan dimana thitung > ttabel. ternyata nilai thitung untuk pengaruh variabel motivasi mengajar terhadap variabel kinerja lebih besar dari pada ttabel, maka dapat disimpulkan bahwa terdapat pengaruh secara signifikan motivasi terhadap kinerja.

Selain sejalan dengan teori ketampilan dan motivasi, beberapa hasil penelitian lainnya menunjukan terdapat hubungan antara keterampilan mengajar guru dan motivasi kerja

Al-Madrasah: Jurnal Ilmiah Pendidikan Madrasah Ibtidaiyah

Vol. 6, No. 2, April-Juni 2022 
Yulia Saraswati, Tita Rosita, Tian Abdul Aziz : Pengaruh Keterampilan Guru Matematika Mengadakan Variasi Dalam Menggunakan Aplikasi Google Meet dan Motivasi Mengajar Terhadap Kinerja Pada Masa Pandemi

terhadap kinerja guru. kemampuan profesional guru dan motivasi kerja terhadap kinerja mengajar guru sekolah dasar. hasil penelitianya bahwa kemampuan professional guru dan motivasi kerja berpengaruh kepada kinerja guru.

\section{KESIMPULAN DAN SARAN}

\section{A. Kesimpulan}

Berdasarkan analisis yang telah dilaksanakan pada Bab IV, temukan dalam penelitian ini adalah sebagai berikut: 1. Terdapat pengaruh keterampilan guru mengadakan variasi mengajar dalam menggunakan aplikasi Google Meet terhadap kinerja guru, artinya meningkatnya keterampilan mengajar dalam menggunakan aplikasi Google Meet akan berpengaruh meningkatnya kinerja guru dalam pembelajaran matematika kelas $\mathrm{V}$.

1. Terdapat pengaruh keterampilan guru mengadakan variasi mengajar dalam menggunakan aplikasi Google Meet terhadap kinerja guru, artinya meningkatnya keterampilan mengajar dalam menggunakan aplikasi Google Meet akan berpengaruh meningkatnya kinerja guru dalam pembelajaran matemaika kelas V. Dari hasil temuan peneliti mengkonfrimasikan bahwa keterampilan guru mengadakan variasi menggunakan aplikasi Google Meet dapat mempengaruhi hasil kinerja guru pada pembelajaran matematika kelas V. Dimana keterampilan variasi guru mengadakan menggunakan aplikasi Google Meet membuat proses pembelajaran antara guru dan siswa tetap terlaksana, guru dengan keterampilan mengajarnya bisa memanfaat media Google Meet sebagai ruang untuk tetap melaksanakan proses belajar bagi siswa dan gurupun dapat menjalankan tugasnya dengam optimal.

2. Terdapat pengaruh motivasi mengajar terhadap kinerja guru, artinya

bahwa meningkatnya motivasi mengajar akan berpengaruh meningkatnya kinerja guru dalam pembelajaran matematika kelas V. Faktor-faktor yang mempengaruhi motivasi berasal ekternal dan internal. Jika guru yang memiliki motivasi tinggi dalam dirinya maka guru akan mengajar secara maksimal dimasa pandemi ini sehingga kinerja gurupun dapat meningkat.

3. Terdapat pengaruh motivasi mengajar terhadap keterampilan guru, artinya bahwa meningkatnya motivasi mengajar akan berpengaruh meningkatnya ketrampilaan guru dalam pembelajaran matematika kelas V. Dalam menumbuhkan keterampilan guru

Al-Madrasah: Jurnal Ilmiah Pendidikan Madrasah Ibtidaiyah Vol. 6, No. 2, April-Juni 2022 
Yulia Saraswati, Tita Rosita, Tian Abdul Aziz : Pengaruh Keterampilan Guru Matematika Mengadakan Variasi Dalam Menggunakan Aplikasi Google Meet dan Motivasi Mengajar Terhadap Kinerja Pada Masa Pandemi

mengadakan variasi menggunakan Google Meet ini tidak lain dipicu oleh motivasi yang berasal dari guru. Semangat dan dorongan inilah yang mampu meninkatkan keterampilan guru mengadakan variasi mengadakan variasi mengajar dalam menggunakan aplikasi Google Meet sebagai media online.

4. Terdapat pengaruh keterampilan guru mengadakan variasi dalam menggunakan aplikasi Google Meet dan motivasi mengajar secara bersama terhadap kinerja pada pembelajaran matematika, Karena, apabila ingin meningkatkan kinerja guru dalam pembelajaran matematika kelas $\mathrm{V}$, facktor-faktor yang mempengaruhi seperti keterampilan guru mengadakan variasi menggunakan aplikasi Google Meet dan motivasi mengajar wajib dipertimbangkan dan diperhatikan. Maka keterampilan dan motivasi mengajar saling mempengaruhi. Sehingga hasil penelitian dengan meningkatnya keterampilan guru mengadakan variasi dalam menggunakan aplikasi Google Meet dan motivasi mengajar guru dapat meningkatkan kinerja guru pada pembelajaran matematika kelas V sd

\section{B. Saran}

Berdasarkan temuan dan kesimpulan hasil penelitian ini yang telah diuraikan sebelumnya, maka dalam peningkatan kinerja guru, maka saran-saran yang dapat diberikan untuk penelitian selanjutnya yaitu sebagai berikut:

1.Bagi guru perlu mensosialisasikan dan mengembangkan penggunaan Google Meet disemua jenjang dalam meningkatkan kualitas guru terutama pada kinerja dan dapat membantu proses belajar bagi siswa. Serta guru harus lebih kreatif dan inovatif dalam memberikan pembelajaran yang menarik bagi siswa tentunya dengan memanfaat video conferens seperti penggunaan Google Meet agar dimasa pandemi ini proses belajar tidak tertinggal serta dapat memberikan semangat motivasi guru untuk meningkatkan kinerja guru dimasa pandemi.

2..Bagi penelitian selanjutnya diharapkan dapat melakukan penelitian di semua jenjang dari SD sampai SMA terkait keterampilan guru mengadakan variasi dalam menggunakan aplikasi Google Meet dan motivasi mengajar terhadap kinerja guru. Pada hasil penelitian ini hanya 8 keterampilan mengajar dan motivasi mengajar yang dapat mempengaruhi kinerja. Contohnya : keterampilan bertanya, ketrampian memberi penguatan, keterampilan mengadakan variasi, ketampilan menjelaskan, keterampilan membuka dan

Al-Madrasah: Jurnal Ilmiah Pendidikan Madrasah Ibtidaiyah Vol. 6, No. 2, April-Juni 2022 
Yulia Saraswati, Tita Rosita, Tian Abdul Aziz : Pengaruh Keterampilan Guru Matematika Mengadakan Variasi Dalam Menggunakan Aplikasi Google Meet dan Motivasi Mengajar Terhadap Kinerja Pada Masa Pandemi

menutup pelajaran, ketrampilam membimbing diskusi kelompok kecil, keterampilan mengelola kelas, dan keterampilan mengajar kelompok kecil dan perorangan.

\section{DAFTAR PUSTAKA}

Agus Gunawan. "Bab II Landasan Teori." Journal of Chemical Information and Modeling 53, no. 9 (2019).

Ahmadi, R. Profesi Keguruan Konsep \& Strategi Mengembangkan Profesi \& Karier Guru. Depok: Aa-Ruzz Media, 2018.

Dr. Sudayono. Metode Penelitian Pendidikan. Jakarta: Kencana, 2016.

Fathinatul Utammimah. E-Book Pengantar E-Learning Dalam Dunia Pendidikan Modern. Malang: UIN Maliki Press (Aggota IKPI), 2015.

Mangkunegara. Manajemen Sumber Daya Manusia Perusahaan. Bandung: Remaja Rosdakarya, 2016.

Marchianti, Ancah Caesarina Novi, Elly Nurus Sakinah, dan Nurud Diniyah. "Efektifitas Penyuluhan Gizi Pada Kelompok 1000 HPK Dalam Meningkatkan Pengetahuan Dan Sikap Kesadaran Gizi.” Journal of Agromedicine and Medical Sciences 3, no. 3 (2017).

Rusman. Model-Model Pembelajaran Mengembangkan Profesionalisme Guru. Jakarta: PT.Raja Grafindo Persada, 2018.

Sugiono. Metode Penelitian Kuantitatif, Kualitatif, Dan R\&D. Bandung: Alfabeta, 2019.

Supardi. Kinerja Guru. Jakarta: Rajawali Pers, 2016.

Wijayanto, A., Yunis, S. dkk. Strategi Pembelajaran PJKR Selama Covid19 (1st Ed.). Tulungagung: Akademia Pustaka, 2020.

Al-Madrasah: Jurnal Ilmiah Pendidikan Madrasah Ibtidaiyah

Vol. 6, No. 2, April-Juni 2022 